F. med. Genet. (1965). 2, 38.

\title{
Muscular Dystrophy (Duchenne) in a Girl with Turner's Syndrome*
}

\author{
PIERRE FERRIER $\dagger$, FRED BAMATTER, and DAVID KLEIN
}

From the Clinique de Pédiatrie and Institut de Génétique médicale, University of Gєneva, Switzerland

According to classical genetics, a recessive sex-linked or X-linked gene manifests its existence phenotypically only in the absence of its normal allele, that is, in the homozygous state or in the absence of a second $\mathrm{X}$ chromosome carrying the normal allele. The latter requirement is met, for instance, in males who have haemophilia as a sex-linked trait: they have only one $\mathrm{X}$ chromosome in their $\mathrm{XY}$ chromosome complement. In females with the usual $\mathrm{XX}$ sex-chromosome composition a gene such as the haemophilia gene is not able to manifest itself, as it is neutralized by the presence of its normal allele on the second $X$. The situation is different in XO females: as in XY males, all recessive genes carried by the single $\mathrm{X}$ chromosome can freely express themselves.

The case reported here is that of a girl with Turner's syndrome and Duchenne type muscular dystrophy. Chromatin negative Turner's syndrome is usually the consequence of a complete or partial (mosaic) XO sex-chromosome complement. Duchenne type muscular dystrophy usually appears to be sex-linked (Morton, Chung, and Peters, 1963; Boyer and Fainer, 1963; Walton, 1964). The present case offers cytogenetical evidence in support of sex linkage and of a permissive effect of abnormal sex-chromosome complement with regard to muscular dystrophy.

\section{Case Report}

This $7 \frac{1}{2}$-year-old girl was the youngest of three sibs. The parents were unrelated and healthy. The mother was 37 and the father 38 years old at the time of birth of the patient. On the paternal side, a first

\footnotetext{
Received September 28, 1964 .

* Part of this work has been completed with the support of the Fonds National Suisse pour la Recherche Scientifique.

† Present address: Department of Pediatrics, University of Washington, Seattle 5, Wash., U.S.A.
}

cousin of the patient, a boy, had a palatoschisis, and-another first male cousin suffered from haemophilia..$\infty$ The mother's side of the family appeared to be normal, 0 but most of these relatives were living in another part of the country. The 14-year-old brother of the patient ${ }_{r}^{-}$ had had progressive pseudohypertrophic muscular dystrophy of the Duchenne type since the age of $7 \stackrel{\overline{3}}{3}$ and had been confined to a wheel chair since the age of I2.

The patient's birth weight was 2,040 g., lengtho $46 \mathrm{~cm}$. Physical and motor development were slow: she sat up by 8 months of age and walked alone ato 20 months. The parents were disturbed by her lack of appetite and extremely poor weight gain in infancy. Growth had always been very slow and regular. Theڤ patient was not having major difficulties at school; $;$ she rated 86 on the Wechsler intelligence scale. At $\Rightarrow$ 6 years of age the parents began to notice that the윽 girl had some difficulty in climbing stairs, tired more easily on exercise, and fell down more often than before. These troubles were mild but progressed? slowly.

Examination at $7 \frac{1}{2}$ years revealed the followingo features: stature $(102 \mathrm{~cm}$.) and weight $(13 \mathrm{~kg}$.) were 0 well below the third percentile for this age (Fig. ra? and b). The lower segment (pubis to sole) was $46 \mathrm{~cm}$., and the span was $98 \mathrm{~cm}$. Her narrow pelvis and broad 3 shoulders and chest, her leanness and the relative muscular prominence further contributed to give to her body the appearance of a miniature male adolescent. $\frac{D}{2}$ Muscular hypertrophy was particularly obvious at the calves. Salient facial features were downward N eye slanting, a few pigmented naevi, large external ears, and a high-arched palate. Permanent incisors $N$ were present. The thyroid was not palpable. There N was no webbing of the neck. There was no evidence $O$ of cardiovascular malformation, and the arterial blood pressure was $105 / 50 \mathrm{~mm}$. Hg. External genitalia were normal female and infantile. The extremities were normal except for the impaired radial adduction of ${ }^{?}$ both wrists (Fig. 2a). Neurological findings were $T$ limited to generalized but moderate muscular weakness, with conservation of the deep tendon reflexes. The gait was normal but the patient needed a support to 


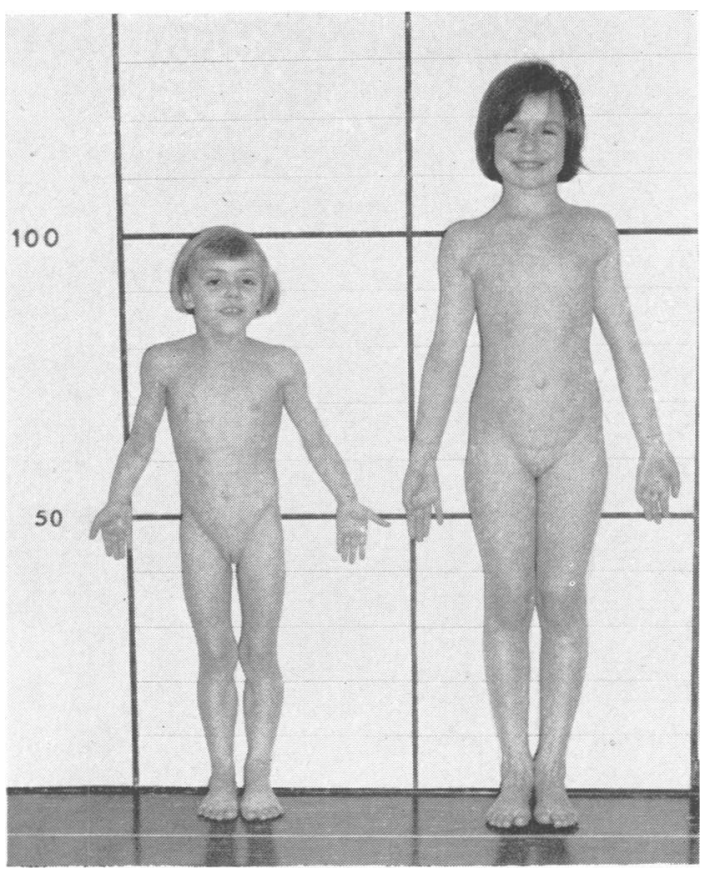

FIG. Ia.

FIG. Ia and $b$. The patient at $7 \frac{1}{2}$ with a healthy girl of the same age. Note the broad shoulders and thorax, the narrow pelvis, and the pseudohypertrophy of the calves.

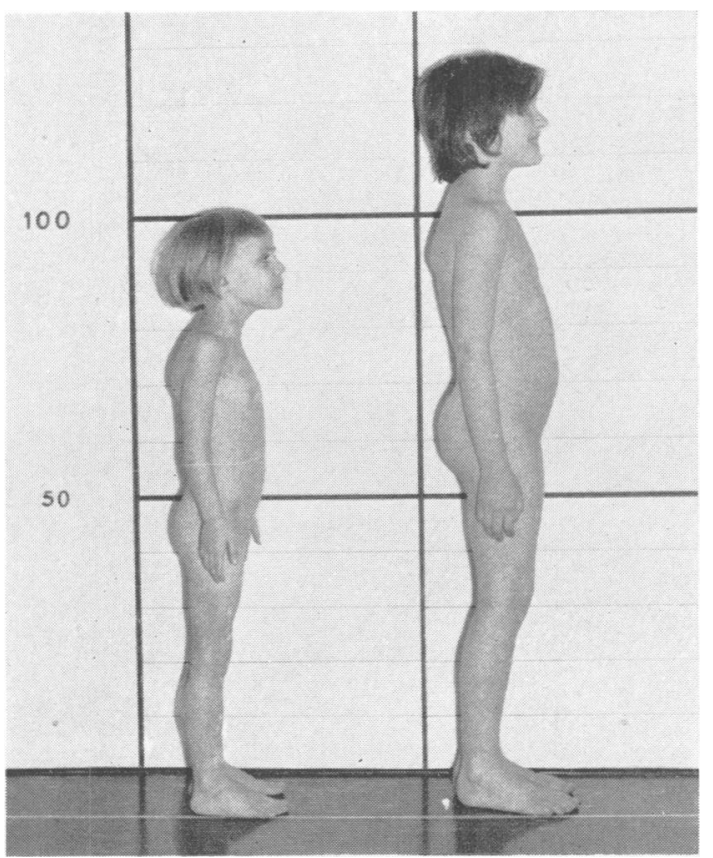

FIG. Ib pull herself up when climbing stairs. She exhibited the classic 'body building' manoeuvre with hands taking support on the thighs when rising up from reclining to upright position. Colour vision, using the Ishihara tables, was found to be normal in the patient as well as in the other members of the family.

Radiographic and Laboratory Data. Radiographs showed bone maturation to be consistent with chronological age. The skull was normal. Both wrists showed the so-called Madelung's deformity (Madelung, 1879) (Fig. 2b), i.e. a pronounced angulation of the distal epiphysis of the radii. An intravenous pyelogram revealed a normal excretory system.

Urinalysis and blood counts were within normal limits.

Enzyme Determinations. Serum creatine phosphokinase activity was measured in Dr Richterich's laboratory in Berne and was found to be increased to $49 \cdot \circ \mathrm{U}$. (normal: $\circ$ to $2 \cdot \circ \mathrm{U}$.). The same determination was repeated 6 months later (at the age of 8) and gave a value of $102 \cdot 0 \mathrm{U}$. The serum of the affected brother was tested also and an activity of $25.5 \mathrm{U}$. was demonstrated, whereas the healthy sister, the mother, and the father had $2 \cdot 3$ to $4 \cdot 0 \mathrm{U}$. and $2 \cdot \mathrm{I} \mathrm{U}$. respectively.

MusCle Biopsy. A biopsy from the right gastrocnemius muscle showed small foci of muscle fibre necrosis with round cell phagocytosis and proliferation of histiocytes.

Blood Group Determinations. Blood samples from the whole family were sent to Dr R. Sanger in London for blood group determinations, particularly regarding the sex-linked $\mathrm{Xg}$ group. All members of this family were $\mathrm{Xg}(\mathrm{a}-)$.

Cytological Data. Buccal smears from the patient were interpreted as showing a negative chromatin pattern. However, in a very small percentage of the nuclei a closer inspection revealed the presence of Barr bodies of smaller than average size (Fig. 3).

Tissue cultures of skin fibroblasts disclosed a mosaic chromosomal complement of the $\mathrm{XO} / \mathrm{Xx}$ type, $\mathrm{x}$ standing for what was interpreted as a centric fragment of an X chromosome (Fig. 4, 5, and 6). However, the possibility of a ring $\mathrm{X}$ chromosome could not be excluded with certainty: 59 cells with 45 chromosomes were counted, and II of them were karyotyped, showing the XO complement; ro cells with 46 chromosomes were counted, and all Io were karyotyped, showing the $\mathrm{Xx}$ complement.

Short-term cultures from peripheral blood leucocytes also revealed the existence of the two cell lines. 6I cells were counted: one had 44 chromosomes, 39 cells had 45 chromosomes, 20 cells had 46, and one cell had 45 or 46. Karyotyping was carried out on 24 metaphase plates: 9 cells were of the 45-XO type, and 13 of the 46-Xx (or XX $\mathrm{Xing}_{\text {Ring }}$ type. Two cells showed a comple- 


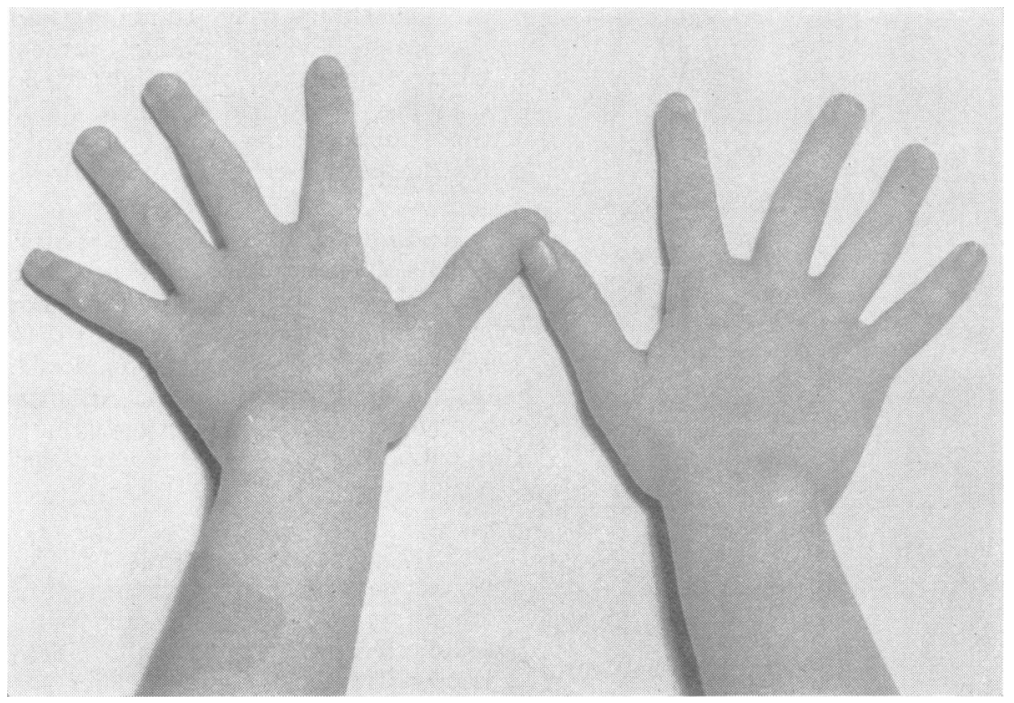

FIg. 2a.

FIG. 2a and b. The wrist deformity due to the abnormal shape of the distal end of the radii (Madelung).

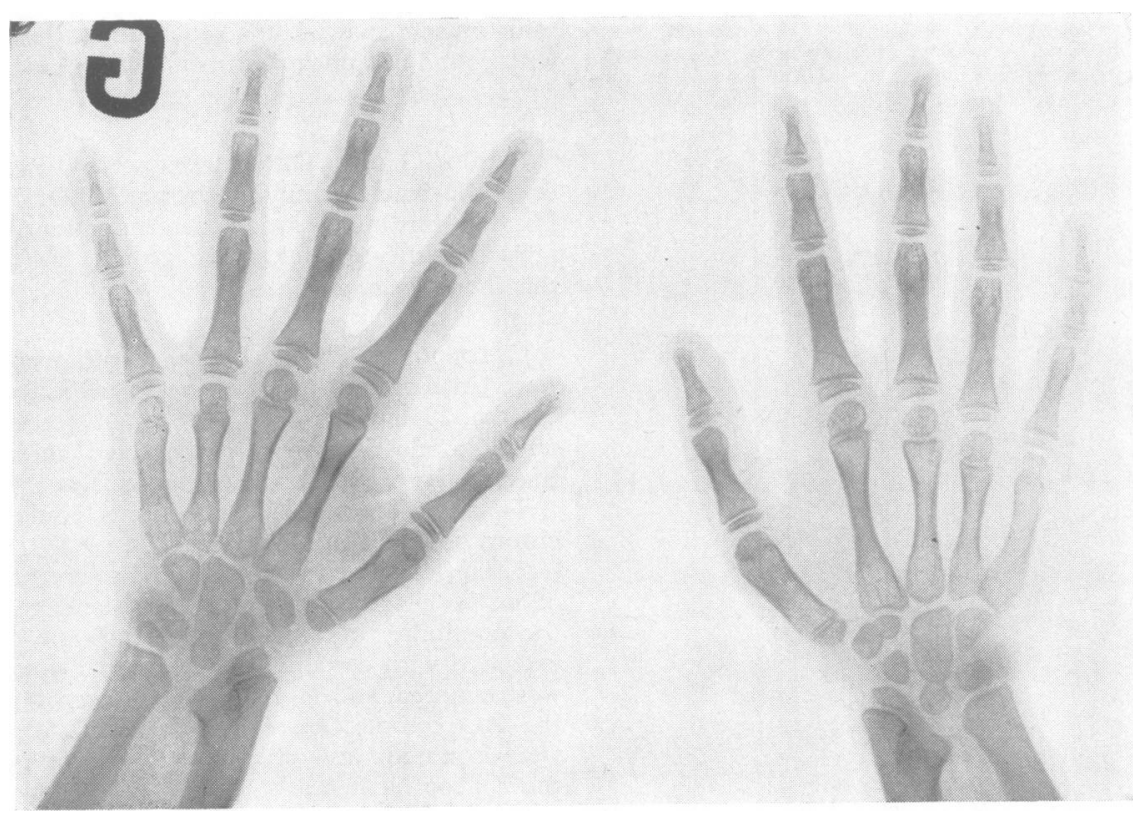

FIG. 2b.

ment of 45 chromosomes with the Xx set, but in each of them a different autosome was missing, indicating that the complement of 45 in these cells was probably due to an artefact.
Discussion

Turner's Syndrome. Turner's syndrome $\frac{\vec{C}}{\mathbb{C}}$ was diagnosed in this patient on the basis of $\frac{\mathrm{O}}{+}$ dwarfism, a wide shield-like thorax, various facial $\stackrel{\AA}{\complement}$ 


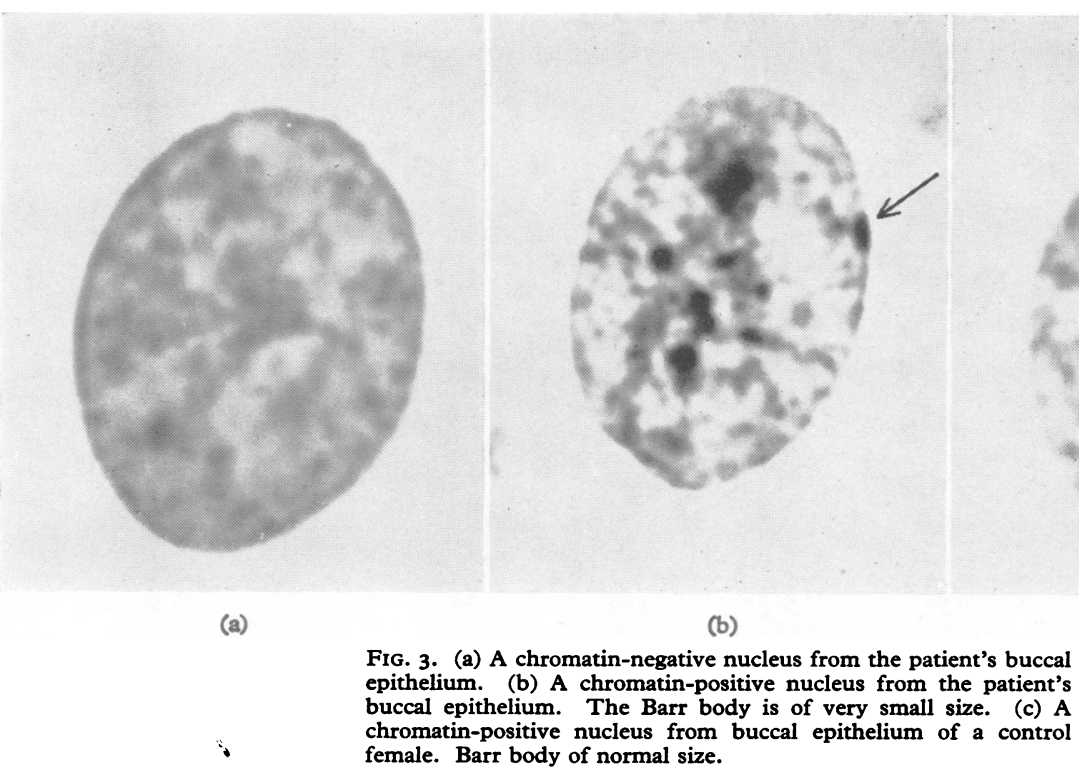

anomalies (Haddad and Wilkins, I959; Lemli and Smith, 1963), and a malformation of the wrist (Kosowicz, 1962; Finby and Archibald, 1963). Sex chromatin and the karyotype findings substantiated the diagnosis. Though an XO chromosome complement remains the basic cytological characteristic of Turner's syndrome, a large number of mosaic cases have now been described (Jacobs, Harnden, Buckton, Court Brown, King, McBride, MacGregor, and Maclean, 1961; De la Chapelle, 1962; Lindsten, 1963; Jones, Ferguson-Smith, and Heller, 1963; Engel, 1964). In the present instance most of the cells had a $45-\mathrm{XO}$ complement, but there were a few 46 chromosome cells possessing one $\mathrm{X}$ chromosome plus a small chromosome, equal or inferior in size to the smallest acrocentrics of the $2 \mathrm{I}-22$ group (Fig. 7 and 8). In some cells this small chromosome had no visible centromere, but in others it had one with two very short arms and it could be interpreted as a deleted $\mathrm{X}$ chromosome. This interpretation was suggested by the fact that in the majority of the cells one of the X chromosomes was missing. The same factor responsible for the complete disappearance of one $X$ may have been at play for the partial deletion of this chromosome in another cellular stem-line in the zygote. Moreover, there are now reports of a certain number of examples of gonadal dysgenesis or Turner's syndrome with an identical mosaic karyotype (Blank, Gordon, and Bishop, I96I ;
Ferrier, Gartler, Waxman, and Shepard, 1962; De la Chapelle, 1962; Jones et al., 1963; Lindsten, 1963; Quinodoz, Ferrier, Ferrier, Zahnd, and Prod'hom, 1964). These patients may or may not exhibit as many malformative stigmata as the purely XO females.

Duchenne Type Muscular Dystrophy. The diagnosis of Duchenne type muscular dystrophy rested upon clinical features such as muscular weakness with muscular pseudohypertrophy, particularly at the calves, the progressive nature of the dystrophy, the positive family history, the serum creatine kinase determinations, and the muscle biopsy. As shown by Ebashi, Toyokura, Momoi, and Sugita (1959), Dreyfus, Schapira, and Demos (1960), and Aebi, Richterich, Stillhart, Colombo, and Rossi (I96I), serum creatine phosphokinase activity is increased in Duchenne muscular dystrophy, particularly in the early stages of the disease, when the patient is still able to walk.

Inheritance of Duchenne Muscular Dystrophy. In the majority of affected families, the study of pedigrees provides evidence in favour of a sex-linked recessive inheritance for this type of muscular dystrophy (Stevenson, 1953; Walton, 1955, 1956). Further evidence comes from the fact that affected boys born of the same mother may be fathered by different men (Walton, 1956), 
Fig. 4. A $45 / \mathrm{XO}$ cell (skin fibroblast, right calf).

and from the study of a family in which a crossingover had possibly occurred between this type of muscular dystrophy and red-green colour blindness (Philip and Walton, 1956).

In some uncommon pedigrees, however, there are affected females as well as affected males, and it is thought that the disease may sometimes be produced by an autosomal recessive gene (Lamy and de Grouchy, 1954; Kloepfer and Talley, 1958; Dubowitz, 1960; Jackson and Carey', 1961).
Recent findings still further complicate the $\tilde{O}^{-}$ issue. Studies in female carriers of the sex-linked N recessive gene responsible for most instances ofo the disease have shown that over $70 \%$ of them can be identified by their moderately increased serum creatine kinase activity (Schapira, Dreyfus,? Schapira, and Demos, 1960; Aebi, Richterich, 7 Colombo, and Rossi, 1962; Hughes, 1962; Rich-O terich, Rosin, Aebi, and Rossi, 1963). Van den Bosch (1963) and Barwick (1963) have reported市 

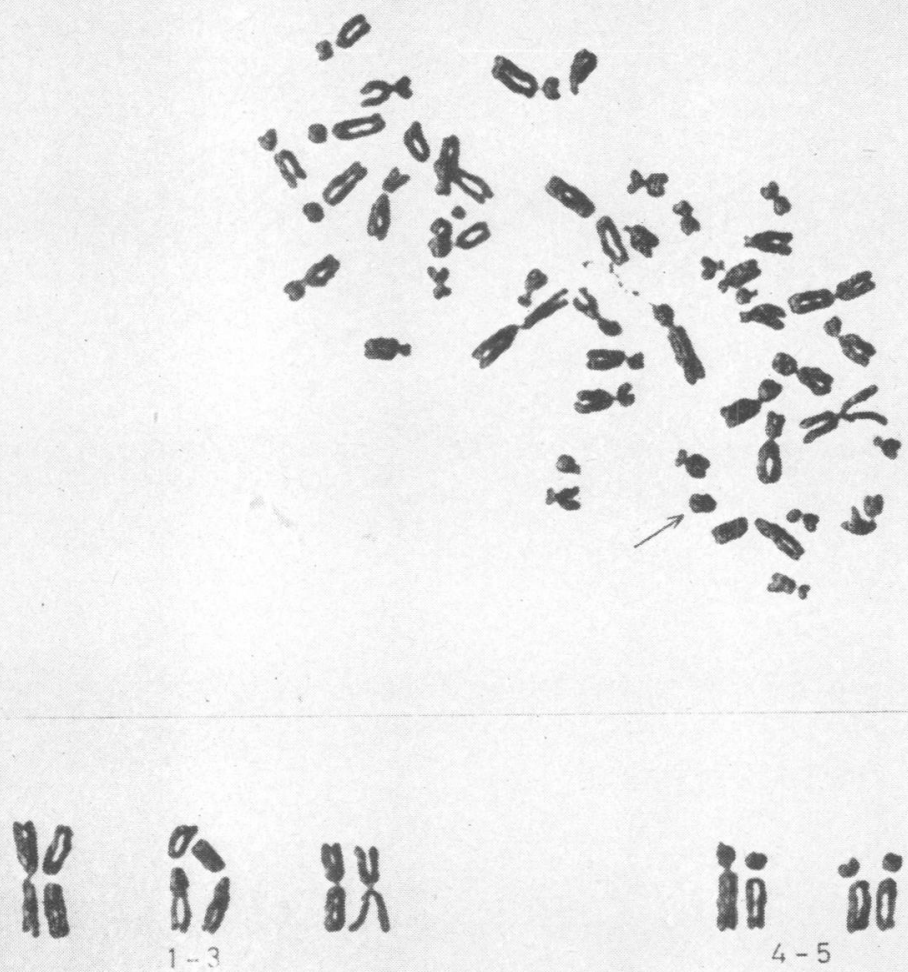

a)

$82 x$

\section{识}
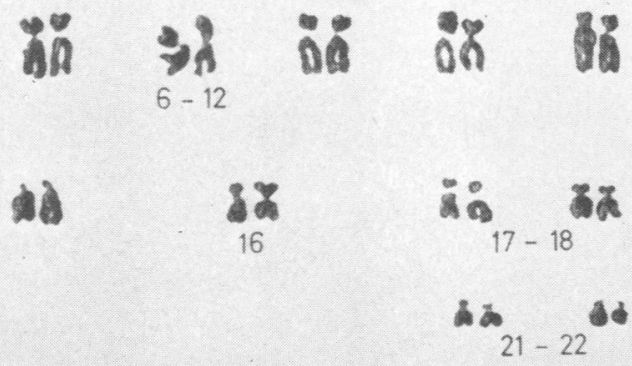

that minor electromyographic anomalies suggestive of a myopathy may also be observed in carriers. Emery (1963) and Pearson, Fowler, and Wright (I963) have shown that minor clinical manifestations such as minimal muscular wasting and pseudohypertrophy of the calves may be present in certain carrier females. Dubowitz (1963a, b) demonstrated that these manifestations were correlated with typical histological changes in the muscles. These observations are in agreement with the Lyon hypothesis (Lyon, I96I, I962) on the random inactivation of one of the $X$ chromosomes in females. In carrier females a certain proportion of the muscle cells are in fact dystrophic, 

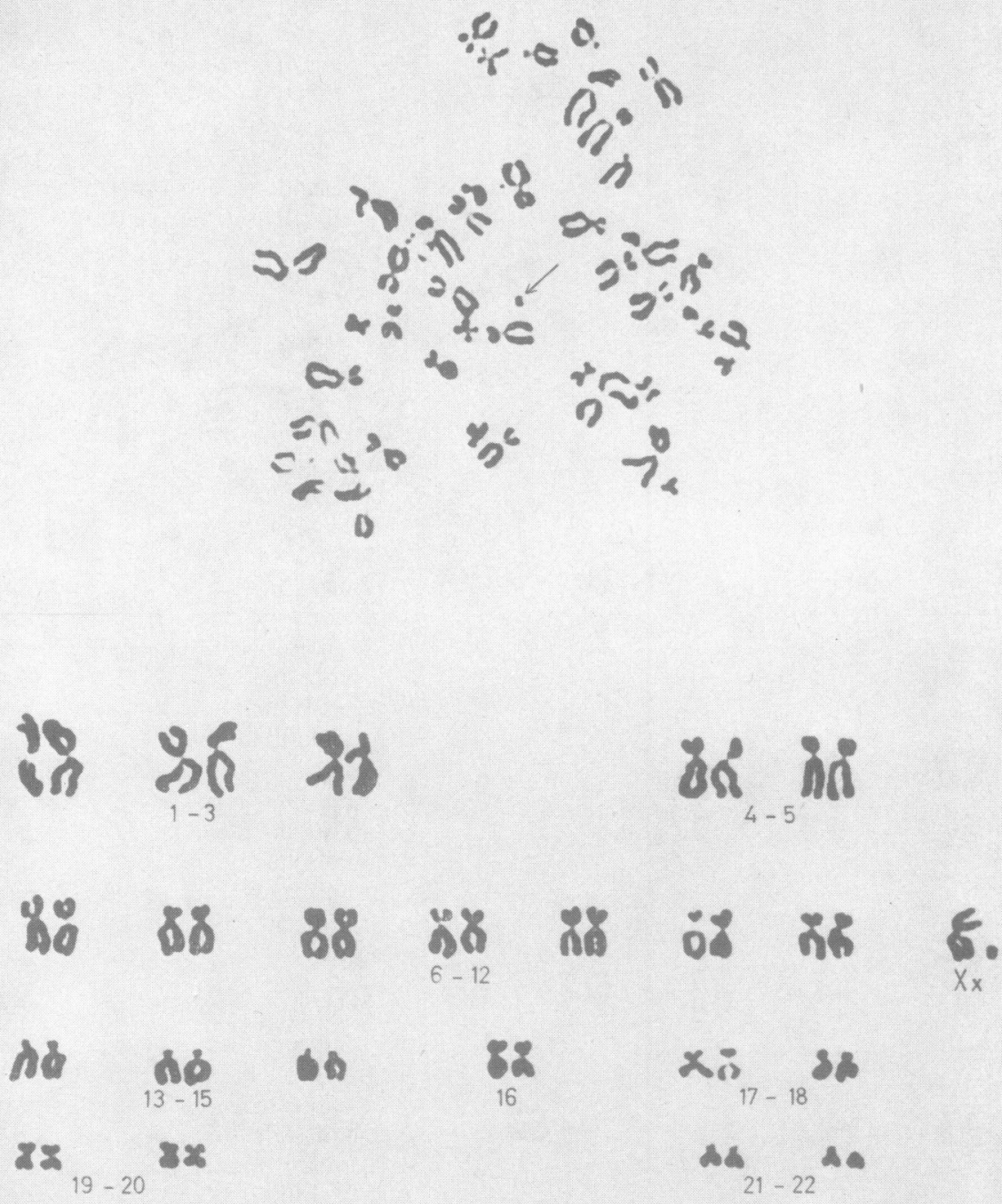

FIG. 6.

due to the inactivation of the $\mathrm{X}$ chromosome carrying the normal gene, but this proportion is usually too small to give rise to clinically detectable muscular weakness (Pearson et al., 1963).

In the present case the pedigree was too rudimentary to ascertain that the disease was transmitted according to a sex-linked mode of inheritance. However, its occurrence in the same sibship in a boy and a XO/Xx mosaic girl, while the normal sister was free of the disease, might be considered as suggestive evidence in favour of the sex-linked $N$ transmission. A similar association of Turner's N syndrome and Duchenne muscular dystrophy has been observed by Walton (I956) in a girl with a negative sex chromatin pattern. Apparently the karyotype of this patient was not established, but $\stackrel{\mathbb{N}}{\rightarrow}$ it was assumed to be $\mathrm{XO}$ and this example is cited by Walton (1964) as evidence in favour of $\overrightarrow{0}$ sex-linkage.

Other but less likely explanations may be put $\frac{?}{\mathbb{Q}}$ 
forward to account for this association, as can be deduced from the above quoted studies. Recessive autosomal inheritance cannot be absolutely ruled out from the pedigree; the association would then lack any cause and effect relationship. The other alternative would be to consider the patient as a carrier with minor clinical manifestations. Her muscle biopsy would be compatible with this hypothesis. However, her serum creatine phosphokinase activity fell within the values obtained in patients with Duchenne muscular dystrophy in the same laboratory (Aebi et al., 1961), and well above those of the carrier mother $(3 \cdot 2 \mathrm{U})$ and possible carrier sister $(2 \cdot 3$ to $4.0 \mathrm{U})$. Finally, her clinical manifestations were more important than the muscle changes without weakness reported in some female carriers (Emery, 1963; Pearson et al., 1963). For these reasons, the hypothesis of a carrier state ought to be discarded.

Origin of Non-disjunction of the $X$ chromosome in Turner's Syndrome. In Turner's syndrome, studies on the inheritance of associated sex-linked characteristics such as colour blindness (Polani, 196I) and $\mathrm{Xg}$ blood group (Lindsten, Fraccaro, Polani, Hamerton, Sanger, and Race, 1963; Lindsten, 1963) point to the maternal origin of the single $\mathrm{X}$ in the majority of cases. If one admits the sex-linked nature of muscular dystrophy in the present patient's family, then the patient is another example of Turner's syndrome with the single $\mathrm{X}$ deriving from the mother, as shown by the clinical and pathological findings. Meiotic non-disjunction in the father accounts for the XO complement in most cases of XO Turner's syndrome. On the other hand, in mosaic cases mitotic non-disjunction in the zygote is more likely to have occurred. If such is the origin of the mosaic in the present patient, one must admit that in mitotic nondisjunction of the $\mathrm{X}$, the paternal $\mathrm{X}$ is preferentially lost (XO cells) or inactivated (Xx cells). So whether the origin of the non-disjunction is meiotic or mitotic does not make much difference: the paternal $\mathrm{X}$ is lost preferentially in Turner's syndrome.

Probability Calculations. The manifestation of a sex-linked trait in a subject with an XO chromosome complement is a statistically predictable event, if the independence of the two is accepted. Its incidence can be calculated to be equal to the product of the frequency of $\mathrm{XO}$ females in the general population $(0.2$ to $0.5 / 1,000$ : Bergemann, 196I; Maclean, Harnden, and Court Brown,
I96I; Court Brown, I962; Nakagome, Hibi, Konoshita, Nagao, and Aikawa, 1963) by the frequency of the $\mathrm{X}$-linked mutant in the same population (279/million for Duchenne muscular dystrophy: Morton et al., 1963). The chance of occurrence of both disorders in the same person, therefore, is of approximately $\mathrm{I} / \mathrm{I} 0$ millions.

\section{Summary}

The case reported is that of a $7 \frac{1}{2}$-year-old girl who suffered from muscular dystrophy of the Duchenne type associated with dwarfism and other characteristics of Turner's syndrome. Her chromosome complement in both skin fibroblasts and peripheral leucocytes was found to be a mosaic of $\mathrm{XO}$ cells and $\mathrm{Xx}(=\mathrm{X}$ and a deleted $\mathrm{X})$ cells. The family pedigree, though not absolutely conclusive, suggested a sex-linked or X-linked inheritance of the muscular dystrophy. The view is expressed that the loss of genetic material, total or sub total, from the $\mathrm{X}$ chromosome was responsible for the clinical manifestation of the disease in this phenotypic female. This is the second recorded instance of such an association. Furthermore, this case is thought to represent another example of Turner's syndrome in which the paternal $\mathrm{X}$ has been preferentially lost or deleted.

Our thanks are due to Dr Richterich and his collaborators, Medizinisch-chemisches Institut der Universität Bern, for the serum enzyme determinations, and to Dr R. Sanger, M.R.C. Blood Group Research Unit, the Lister Institute, London, who studied the blood groups. We are also grateful to Dr. S. Gartler, University of Washington, Seattle, for reading the manuscript.

\section{REFERENCES}

Aebi, U., Richterich, R., Colombo, J. P., and Rossi, E. (I962) Progressive muscular dystrcphy. II. Biochemical identification of the carrier state in the recessive sex-linked juvenile (Duchenne) type by serum creatine-phosphokinase determinations. Enzymol. biol. clin., $\mathrm{x}, 6 \mathrm{r}$.

- - Stillhart, H., Colombo, J. P., and Rossi, E. (I96I) Progressive Muskeldystrophie. III. Serumenzyme bei der Muskeldystrophie im Kindesalter. Helv. paediat. Acta, 16, 543. Barwick, D. D. (1963). In Research in Muscular Dystrophy (Muscular Dystrophy Group), p. 10. Pitman, London.

Bergemann, E. (I96I). Geschlechtschromatinbestimmungen am Neugeborenen. Schweiz. med. Wschr., 91, 292.

Blank, C. E., Gordon, R. R., and Bishop, A. (I96I). Atypical Turner syndrome. Lancet, $\mathrm{I}, 947$.

Boyer, S. H., IV, and Fainer, D. C. (1963). Genetics and diseases of muscle. Amer. F. Med., 35, 622.

Court Brown, W. M. (1962). Sex chromosomes and the law. Lancet, 2, 508.

De la Chapelle, A. (1962). Cytogenetical and clinical observations in female gonadal dysgenesis. Acta endocr. (Kbh.), Suppl. 65.

Dreyfus, J. C., Schapira, G., and Demos, J. (1960). Étude de la créatine-kinase sérique chez les myopathes et leurs familles. Rev. frans. Étud. clin. biol., 5, 384. 
Dubowitz, V. (1960). Progressive muscular dystrophy of the Duchenne type in females and its mode of inheritance. Brain, 83, 432.

432. (1963a). Myopathic changes in a muscular dystrophy carrier. f. Neurol. Neurosurg. Psychiat., 26, 322.

(1963b). Myopathic changes in muscular dystrophy carriers. Proc. roy. Soc. Med., 56, 8 ro.

Ebashi, S., Toyokura, Y., Momoi, H., and Sugita, H. (1959). High creatine phosphokinase activity of sera of progressive muscular dystrophy. F. Biochem. (Tokyo), 46, ro3.

Emery, A. E. H. (1963). Clincal manifestations in two carriers of Duchenne muscular dystrophy. Lancet, I, I 126.

Engel, E. (1964). La dysgénésie gonadique (syndrome de Turner): une affection rare mais riche d'enseignement. Étude chromosomique de 35 cas. Schweiz. med. Wschr., 94, 906.

Ferrier, P., Gartler, S. M., Waxman, S. H., and Shepard, T. H., II (1962). Abnormal sexual development associated with sex chromosome mosaicism. Pediatrics, 29, 703.

Finby, N., and Archibald, R. M. (1963). Skeletal abnormalities associated with gonadal dysgenesis. Amer. F. Roentgenol., 89, 1222.

Haddad, H. M., and Wilkins, L. (1959). Congenital anomalies associated with gonadal aplasia. Pediatrics, 13, 885.

Hughes, B. P. (1962). Serum enzymes in carriers of muscular dystrophy. Brit. med. F., 2, 963.

Jackson, C. E., and Carey, J. H. (I96I). Progressive muscular dystrophy: autosomal recessive type. Pediatrics, 28, 77

Jacobs, P. A., Harnden, D. G., Buckton, K. E., Court Brown, W. M., King, M. J., McBride, J. A., MacGregor, T. N., and Maclean, N. (196I). Cytogenetic studies in primary amenorrhoea. Lancet, $\mathrm{I}, \mathrm{I} 183$.

Jones, H. W., Ferguson-Smith, M. A., and Heller, R. H. (1963). The pathology and cytogenetics of gonadal agenesis. Amer. $\mathcal{F}$. Obstet. Gynec., 87, 578 .

Kloepfer, H., and Talley, C. (1958). Autosomal recessive inheritance of Duchenne-type muscular dystrophy. Ann. hum. Genet. 22, 138 .

Kosowicz, J. (I962). The carpal sign in gonadal dysgenesis. $\mathcal{f}$. clin. Endocr., 22, 949.

Lamy, M., and Grouchy, J. de (1954). L'hérédité de la myopathie (formes basses). F. Génét. hum., 3, 219.

Lemli, L., and Smith, D. W. (I963). The XO syndrome: a study of the differentiated phenotype in 25 patients. $\mathcal{F}$. Pediat., 63, 577.

Lindsten, J. (1963). The Nature and Origin of $\boldsymbol{X}$ Chromosome Aberrations in Turner's Syndrome: a cytogenetical and clinical study of 57 patients. Almqvist and Wiksell, Stockholm.

- Fraccaro, M., Polani, P. E., Hamerton, J. L., Sanger, R., and Race, R. R. (1963). Evidence that the Xg blood group genes are on the short arm of the $\mathrm{X}$ chromosome. Nature (Lond.), 197, 648.
Lyon, M. F. (I96I). Gene action in the X-chromosome of the mouse(D (Mus musculus L.). ibid., 190, 372.

(1962). Sex chromatin and gene action in the mammalian? X-chromosome. Amer. F. hum. Genet., 14, 135.

Maclean, N., Harnden, D. G., and Court Brown, W. M. (I96r). $\overline{\overline{\bar{\omega}}}$ Abnormalities of sex chromosome constitution in newborn babies. Lancet, 2, 406.

Madelung, O. W. (1879). Die spontane Subluxation der Hand $\bar{O}$ nach vorne. Langenbeck's Arch. klin. Chir., 23, 395.

Morton, N. E., Chung, C. S., and Peters, H. A. (1963). Genetics of muscular dystrophy. In Muscular Dystrophy in Man and Animals, ed. G. H. Bourne and M. N. Golarz, p. 323. Karger, Basle and New York.

Nakagome, Y., Hibi, I., Konoshita, K., Nagao, T., and Aikawa, $\vec{\sim}$ M. (1963). Incidence of Turner's syndrome in Japanese dwarfed. girls. Lancet, $2,412$.

Pearson, C. M., Fowler, W. M., and Wright, S. W. (1963). X- $\vec{\omega}$ chromosome mosaicism in females with muscular dystrophy. Proc. nat. Acad. Sci. (Wash.), 50, 24.

Philip, U., and Walton, J. N. (I956). Colour blindness and the Duchenne-type muscular dystrophy. Ann. hum. Genet., 21, 155.

Polani, P. E. (196I). The sex chromosomes in Klinefelter's syn-" drome and in gonadal dysplasia. Evidence for non-disjunction, $\dot{\omega}$ cleavage loss or other sex-chromosome aberration in man and the function of the $\mathrm{Y}$ chromosome. In Molecular Genetics and Human Disease, ed. L. I. Gardner, p. 153. Thomas, Springfield, Illinois.

Quinodoz, J. M., Ferrier, P., Ferrier, S., Zahnd, G., and Prod'hom, S. (1964). Le syndrome de Turner: à propos de six observations. Helv. med. Acta, 31, 1 .

Richterich, R., Rosin, S., Aebi, U., and Rossi, E. (1963). Pro- $\frac{\rho}{\partial}$ gressive muscular dystrophy. V. The identification of the carrier $\rightarrow$ state in the Duchenne type by serum creatine kinase determination. Amer. F. hum. Genet., 15, 133.

Schapira, F., Dreyfus, J. C., Schapira, G., and Demos, J. (1960) Etude de l'aldolase et de la créatine kinase du sérum chez les mères de myopathes. Rev. franc. Étud. clin. biol., 5, 990.

Stevenson, A. C. (1953). Muscular dystrophy in Northern Ireland. I. An account of the condition in $5 \mathrm{I}$ families. Ann. Eugen. (Lond.), r8, 50.

Van den Bosch, J. (1963). In Research in Muscular Dystrophy (Muscular Dystrophy Group), p. 23. Pitman, London.

Walton, J. N. (I955). On the inheritance of muscular dystrophy. Ann. hum. Genet., 20, $\mathrm{I}$ (1956). The inheritance of muscular dystrophy: further observations. ibid., $21,40$.

(1964). Muscular dystrophy: some recent advances in knowledge. Brit. med. $\mathcal{F}$., I, 1271 and 1344 . 